\title{
Effect of Ionic Strength on Porphyrin Drugs Interaction with Quadruplex DNA Formed by the Promoter Region of C-myc and Bcl2 Oncogenes
}

\author{
Narayana Nagesh, ${ }^{1}$ Varun K. Sharma, ${ }^{1}$ A. Ganesh Kumar, ${ }^{2}$ and Edwin A. Lewis ${ }^{3}$ \\ ${ }^{1}$ Department of Biophysics, Center for Cellular and Molecular Biology, Hyderabad-500 007, India \\ ${ }^{2}$ Department of Biomedical Engineering, Sathyabama University, Chennai-600 087, India \\ ${ }^{3}$ Department of Chemistry, Mississippi State University, Mississippi State, MS 39762, USA
}

Correspondence should be addressed to Narayana Nagesh, nagesh5112@yahoo.co.in

Received 29 March 2009; Revised 10 June 2009; Accepted 29 July 2009

Academic Editor: Jyoti Chattopadhyaya

Copyright ( $) 2010$ Narayana Nagesh et al. This is an open access article distributed under the Creative Commons Attribution License, which permits unrestricted use, distribution, and reproduction in any medium, provided the original work is properly cited.

C-myc and Bcl2 are well characterized oncogenes that are capable of forming G-quadruplex structures. Promoter regions of Cmyc and Bcl2 forming G-quadruplex structures are chemically synthesized and G-quadruplex structure is formed in presence of $100 \mathrm{mM}$ potassium ion. Three different porphyrin drugs, namely TMPyP2, TMPyP3, and TMPyP4 are allowed to interact with quadruplex DNA complex and the site and nature of interaction are studied. Drug interactions with quadruplex DNA were carried out in different potassium ionic strengths using fluorescence spectroscopy. It is found that fluorescence hypochromicity decreases with an increase in ionic strength in the case of TMPyP4, TMPyP3, and TMPyP2. Fluorescence titration studies and Job plots indicate that four molecules of TMPyP4, two molecules of TMPyP3 and TMPyP2 are interacting with one molecule of quadruplex DNA.

\section{Introduction}

$\mathrm{Bcl} 2$ (B-cell/lymphoma-2) is a proto-oncogene which encodes for $25 \mathrm{KD}$ protein which has a peculiar function of blocking programmed cell death without affecting proliferation [1]. There are about 25 genes in the $\mathrm{Bcl} 2$ family. The $\mathrm{Bcl} 2$ gene is known to be responsible for a number of cancers like melanoma, breast, prostate, lung carcinoma, schizophrenia, and autoimmunity [2]. An increase in $\mathrm{Bcl} 2$ levels in the cell is reported to lead to poor prognosis [3]. Hence control of the production of $\mathrm{Bcl} 2$ in a cell has become a significant area of research. Like $\mathrm{Bcl} 2, \mathrm{C}-\mathrm{myc}$ is also an oncogene which has a $\mathrm{G}$-quadruplex forming sequence in its promoter region. The protein product of C-myc proto-oncogene controls a variety of genes that together enhance proliferation of cell $[4,5]$. $\mathrm{C}$-myc is overexpressed in many human cancers cells like leukemia, lung, breast, pancreatic, cervical, etc, [6-8]. The role of G-quadruplexes in cancer therapeutics is increasing. Work is under way in many laboratories elsewhere to identify a suitable synthetic compound or macromolecul, which can stabilize the quadruplex complex in vivo [9]. Many synthetic chemicals were tested for their interaction with quadruplex DNA. Few among them are anthraquinones [10], acridines [11], perylenes [12], and triazines [13, 14]. Porphyrins are chemical compounds, until that can interact with quadruplex DNA structure and stabilize them $[15,16]$. Today, there has been controversy in the nature and site of poprhyrin binding to quadruplex DNA structure. Kimura et al. [17] have studied the interaction between G-quadruplexTMPyP4 using 2-aminopurine substituted human telomeric DNA sequence. Han et al. [18] have demonstrated that TMPyP4 is a suitable telomerase inhibitor because of its low toxicity.

Different TMPyP4 binding modes to DNA are reported in the literature, like intercalation between the G-C base pairs [19, 20], binding to major groove [21] and minor groove $[22,23]$, and binding to the DNA surface [24]. Haq et al. [25] have studied the binding of cationic porphyrin 
to G-quadruplex DNA using ITC, UV-Vis spectroscopy and have shown that the stoichiometry of porphyrin binding to G-quadruplex DNA depends on the number of intervals between successive G-tetrad planes. Freyer et al. [26] have recently reported that the binding of TMPyP4 to c-myc NHE III promoter is in the ratio of $4: 1$, using microcalorimetric and spectroscopic techniques.

\section{Materials and Methods}

2.1. Oligonucleotide Synthesis. For this study, two different quadruplex forming oncogenic sequences, corresponding to $\mathrm{Bcl} 2$ and $\mathrm{C}-\mathrm{myc}$ promoter regions were synthesized and their interactions with three different porphyrin drugs were studied. The sequences of oligonuclotides used in the present study are shown below. The structure of G-quadruplex DNA and porphyrin drugs is shown in Figure 1. All the structures shown in Figure 1 are drawn using ACD/ChemSketch (Version 12):

\section{Bcl2 - CGG GCG CGG GAG GAA GGG GGC GGG AGC \\ C-myc - TGG GGA GGG TGG GGA GGG TGG GGA AGG}

The 27Bcl2 and C-myc oligonucleotide stock solutions were prepared by dissolving each oligonucleotide into $100 \mathrm{mM}$ KBPES buffer $\left(0.01 \mathrm{M} \mathrm{KH}_{2} \mathrm{PO}_{4}, 0.01 \mathrm{M} \mathrm{K}_{2} \mathrm{HPO}_{4}\right.$, $0.001 \mathrm{M}$ EDTA, $0.02-0.6 \mathrm{M} \mathrm{KCl}, \mathrm{KOH}$ added drop wise to $\mathrm{pH}$ 7.0). DNA samples were dialyzed (1000 molecular weight cutoff membrane) against two changes of buffer (1L, 24 hours each) at $4^{\circ} \mathrm{C}$. Concentration of all the oligonucleotides was measured using UV-Vis spectrophotometry with molar extinction coefficients determined by using the nearest neighbor calculation for single stranded DNA [27] and the absorbance of thermally denatured constructs extrapolated back to $25^{\circ} \mathrm{C}$ and/or a total phosphate analysis technique [28]. The extinction coefficient determined for two G-quadruplexes by these techniques was $€_{254}=$ $207840 \mathrm{M}^{-1} \mathrm{Cm}^{-1}(27 \mathrm{Bcl} 2)$ and $€_{260}=215330 \mathrm{M}^{-1} \mathrm{Cm}^{-1}$ (c-myc), respectively.

The cationic porphyrins (TMPyP4, TMPyP3, and TMPyP2) were purchased from Frontier Scientific (Logan, Utah, USA). All the porphyrin drugs were used without further purification. The porphyrin solutions were prepared by dissolution of each drug into a measured volume of final dialysate from the appropriate oligonucleotide solution preparation as the buffer. The concentration of each porphyrin drug was calculated using the molar extinction coefficient $€_{424}=2.26 \times 10^{5} \mathrm{M}^{-1} \mathrm{Cm}^{-1}[29], €_{417}=2.50 \times$ $10^{5} \mathrm{M}^{-1} \mathrm{Cm}^{-1}$ [30], $€_{414}=1.82 \times 10^{5} \mathrm{M}^{-1} \mathrm{Cm}^{-1}$ [31] for TMPyP4, TMPyP3, and TMPyP2, respectively.

2.2. CD Experimental Studies. Circular dichroism experiments were performed using a JASCO 815 CD spectropolarimeter (Jasco, Tokyo, Japan). The CD spectra were recorded from 200 to $500 \mathrm{~nm}$ for characterizing the Gquadruplex DNA and for studying induced $\mathrm{CD}$ by porphyrins. For each $\mathrm{CD}$ experiment, $5 \times 10^{-6} \mathrm{M}$ G-quadruplex
DNA was used. CD spectra were recorded using $10 \times 10^{-6} \mathrm{M}$ (1:2) and $20 \times 10^{-6} \mathrm{M}(1: 4)$ TMPyP4. CD titrations were done in $100 \mathrm{mM}$ KBPES buffer $(\mathrm{pH} 7.0)$ at $25^{\circ} \mathrm{C}$. TMPyP4 was added using a calibrated micropipette. Each CD spectrum is recorded three times, and the average of 3 scans is considered.

2.3. Fluorescence Experiments. Fluorescence emission spectra were measured at $25^{\circ} \mathrm{C}$ using a FluoroMax-3 spectrofluorimeter (Horiba Jobin Yvon, Edison, NJ) using a $1 \mathrm{~cm}$ path length quartz cuvette. G-quadruplex DNA samples were measured in $2 \mathrm{~mL}$ of $100 \mathrm{mM}$ KBPES buffer ( $\mathrm{pH} 7.0$ ). Through out the fluorescence experiment, concentration of G-quadruplex DNA is kept constant $(200 \mathrm{nM})$ and titrated with increasing concentrations of cationic porphyrin (0 to $1200 \mathrm{nM}$ ). Fluorescence spectra were recorded after each addition of porphyrin to the fluorescent cuvette. Gquadruplex DNA and porphyrin drug mixture volume were kept constant throughout the fluorescence titration $(2 \mathrm{~mL})$. After each titration, the quartz cuvette was thoroughly washed with distilled water and dilute nitric acid (approximately $0.1 \mathrm{~N}$, nitric acid) to remove traces of porphyrin sticking to the walls of quartz cuvette. TMPyP4, TMPyP3, and TMPyP2 were excited at $433 \mathrm{~nm}, 417 \mathrm{~nm}$, and $424 \mathrm{~nm}$, respectively and emission spectra for each titration were collected from 600 to $800 \mathrm{~nm}$. Each spectrum was recorded three times and the average of three scans was taken. The difference in fluorescence emission maxima before and after the addition of G-quadruplex DNA was plotted against concentration of porphyrin to obtain the porphyrin-G-quadruplex binding curve. In the fluorescence binding curves (Figure 4), the points of intersection of two extrapolated lines (initial and final), at saturation levels, will indicate the stoichiometry of G-quadruplex DNA and porphyrin drugs.

To investigate the effect of ionic strength on fluorescence hypochromicity (\% FH), four different KBPES buffer solutions ( $\mathrm{pH}$ 7.0) with increasing concentration of $\mathrm{K}(\mathrm{I})$ ion were prepared. The KBPES ( $\mathrm{pH} 7.0$ ) buffer solutions used in the present study contained $30 \mathrm{mM}, 100 \mathrm{mM}, 200 \mathrm{mM}$, and $600 \mathrm{mM}$ of potassium ion.

2.4. UV-Vis Spectroscopic Titrations. UV-Vis spectroscopic titrations were performed using an Agilent 8453 diode array (Agilent, Santa Clara, CA) at $25^{\circ} \mathrm{C}$ using a $1 \mathrm{~cm}$ path length quartz cuvette. Stock solutions of $10 \mu \mathrm{M}$ porphyrin and $10 \mu \mathrm{M}$ of G-quadruplex DNA were prepared in $100 \mathrm{mM}$ KBPES buffer ( $\mathrm{pH}$ 7.0). Two series of solutions were used for the experiments. First two $\mathrm{mL}$ of dilute G-quadruplex DNA $(10 \mu \mathrm{M})$ were placed in a $1 \mathrm{~cm}$ path length quartz cuvette, and twenty five $\times 50 \mu \mathrm{L}$ injections of porphyrin solution $(10 \mu \mathrm{M})$ were added manually. In the second part, two $\mathrm{mL}$ of dilute cationic porphyrin solution $(10 \mu \mathrm{M})$ were used and twenty five $\times 50 \mu \mathrm{L}$ injections of G-quadruplex DNA solution were added. Absorption spectra were collected from $350 \mathrm{~nm}$ to $500 \mathrm{~nm}$. The quartz cells were thoroughly cleaned with distilled water and $0.1 \mathrm{~N}$ nitric acid to remove traces of porphyrin that were deposited on the walls of quartz cell. The 


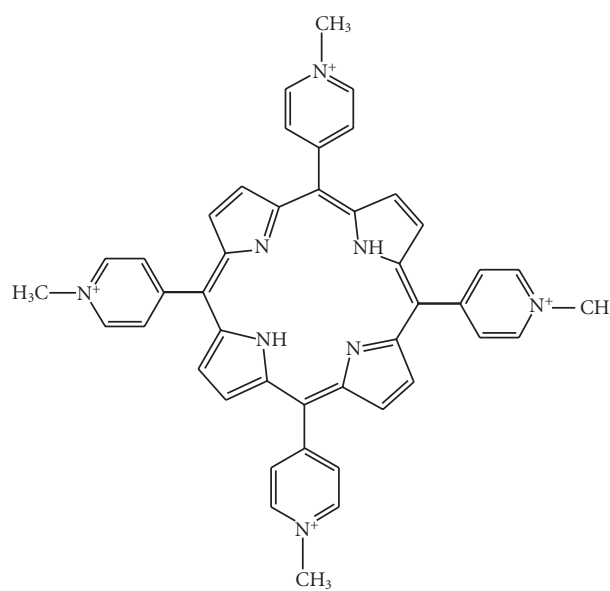

TMPyP4

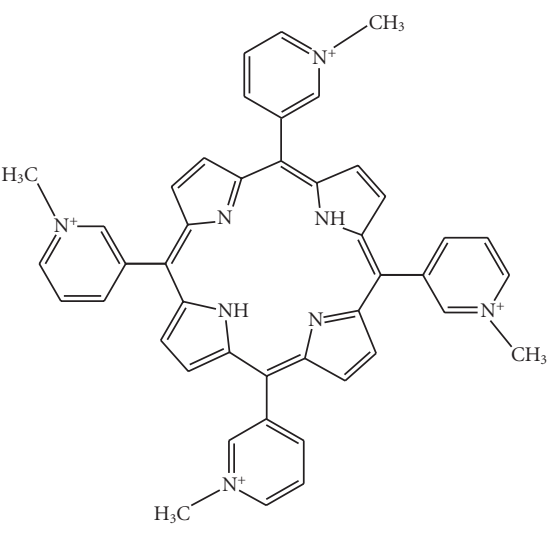

TMPyP3

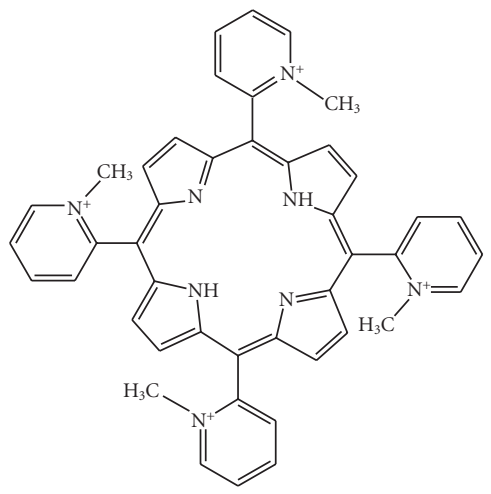

TMPyP2

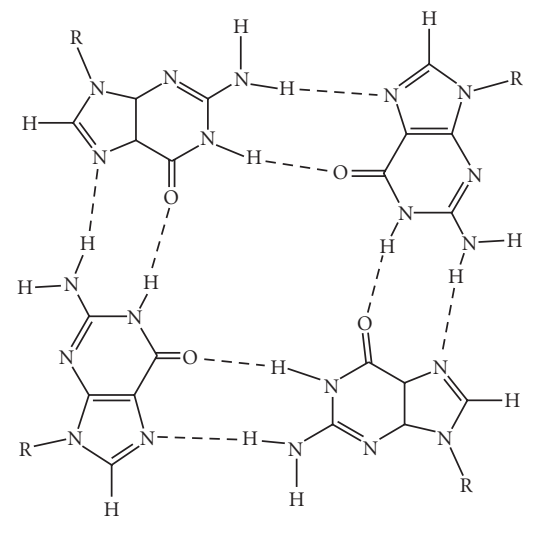

G-quadruplex

Figure 1: The structures of G-quadruplex DNA and TMPyP2, TMPyP3, and TMPyP4.

difference in the absorption maxima of the soret band was plotted versus the prophyrin mole fraction to generate a Job plot [32-34].

UV-Vis absorption titrations were done by adding Gquadruplex DNA stock solution $(200-350 \mathrm{nM})$ in $100 \mathrm{mM}$ KBPES buffer ( $\mathrm{pH}$ 7.0) to the quartz cuvette containing approximately $1 \mu \mathrm{M}$ porphyrin solution prepared in the same buffer. G-quadruplex DNA and porphyrin samples were freshly prepared before performing the experiment. UV spectra were collected from $200 \mathrm{~nm}$ to $500 \mathrm{~nm}$. The titrations were carried out until the porphyrin soret band remains at a fixed wavelength upon five successive additions of Gquadruplex DNA.

\section{Results and Discussion}

3.1. CD Studies. The CD spectrum (Figure 2(a)) shows a prominent positive peak at $265 \mathrm{~nm}$ and a small hump at $295 \mathrm{~nm}$, indicating that the $27 \mathrm{Bcl} 2$ is forming antiparallel quadruplex structure in solution. On addition of TMPyP4 (at $1: 2$ and $1: 4$ DNA : TMPyP4 ratio) a weak induced CD band (ICD) is seen around $435 \mathrm{~nm}$, indicating that TMPyP4 is efficiently interacting with quadruplex DNA. Whereas Figure 2(b) demonstrates comparatively weaker interaction of TMPyP4 with C-myc quadruplex DNA. Furthermore, the CD spectrum shows a positive peak at $265 \mathrm{~nm}$. This indicates that it is forming parallel quadruplex DNA structure in solution. When $\left(10 \times 10^{-6} \mathrm{M}\right)$ and $\left(20 \times 10^{-6} \mathrm{M}\right)$ concentrations of TMPyP4 is added to $27 \mathrm{Bcl} 2$ quadruplex DNA $\left(5 \times 10^{-6} \mathrm{M}\right)$, a negative cotton effect is observed. Small or no cotton effect is seen, when double and quadruple concentrations of drug are added to $5 \times 10^{-6} \mathrm{M}$, C-myc DNA. A negative cotton effect in the case of $27 \mathrm{Bcl} 2$ is observed due to the difference in the conformation of Bcl2 quadruplex DNA. Occurrence of induced CD at $435 \mathrm{~nm}$ and negative cotton effect at $265 \mathrm{~nm}$ indicates that $\mathrm{Bcl} 2$ quadruplex complex has a marginally better interaction efficiency with TMPyP4.

3.2. UV-Titration Studies. UV-Vis spectroscopy is an excellent technique for finding the extent of drug interaction with DNA. In all the drug-DNA interactions, the soret band has shown a red shift. The soret band has shifted from $423 \mathrm{~nm}$ to $441 \mathrm{~nm}(18 \mathrm{~nm}$ shift $)$ in case of TMPyP4 and the isobestic point is prominent at $436 \mathrm{~nm}$ (UV-Vis spectra are similar for 


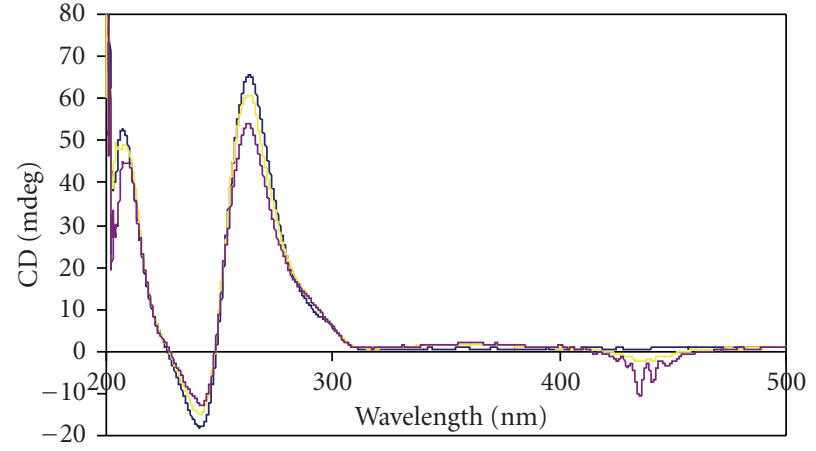

(a)

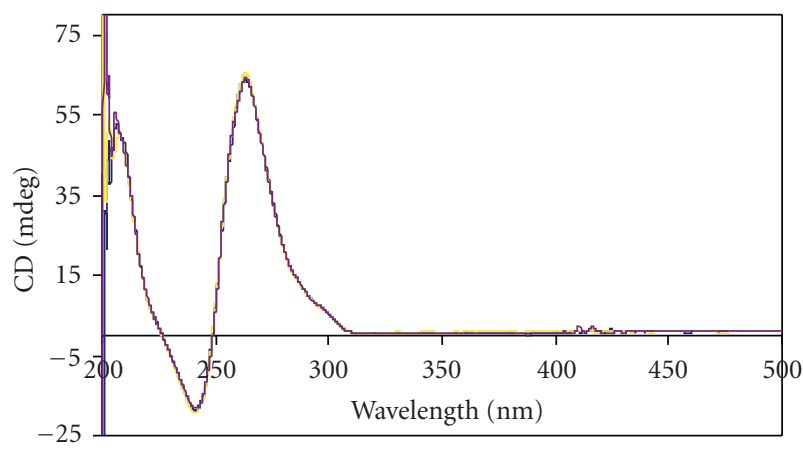

(b)

FIGURE 2: (a) CD spectra for the 27Bcl2 mid promoter sequence, wavelength in nm is plotted on $x$-axis, and Ellipticity, $\theta$, is plotted on the $y$-axis in mdeg. The $5 \times 10^{-6} \mathrm{M}$ quadruplex DNA is considered for each CD experiment. CD spectra are recorded at $1: 2$ and $1: 4$ quadruplex DNA: TMPyP4 stoichiometry. Each spectrum is recorded thrice, and the average of the three runs is considered. (b) CD spectra for the C-myc sequence, wavelength in $\mathrm{nm}$ is plotted on $x$-axis and Ellipticity, $\theta$, is plotted on the $y$-axis in mdeg. The $5 \times 10^{-6} \mathrm{M}$ quadruplex DNA is considered for each CD experiment. CD spectra are recorded at $1: 2$ and $1: 4$ quadruplex DNA: TMPyP4 stoichiometry. Each spectrum is recorded thrice, and the average of the three runs is considered.

TABLE 1: UV-Vis absorption titration parameters for TMPyP4, TMPyP3, and TMPyP2 with four different Bcl2 and C-myc G-quadruplex DNA. Soret band hypochromicity is calculated using the formula: \% Hypochromicity $=\left[\left(€_{\text {free }}-€_{\text {bound }}\right) / €_{\text {free }}\right] \times 100$. $€_{\text {free }}$ and $€_{\text {bound }}$ are the extinction coefficient of free and bound porphyrin, respectively.

\begin{tabular}{llccr}
\hline S. No. & $\begin{array}{l}\text { Name of quadrupelx DNA } \\
\text { and cationic porphyrin }\end{array}$ & Soret band shift $(\mathrm{nm})$ & Isobestic point $(\mathrm{nm})$ & Percentage hypochromicity \\
\hline 1. & 27Bcl2-TMPyP4 & $423-441$ & 435.5 & $59.7 \%$ \\
2. & 27Bcl2-TMPyP3 & $417-431$ & 426.5 & $41.5 \%$ \\
3. & 27Bcl2-TMPyP2 & No shift & 422.0 & $23.0 \%$ \\
4. & C-myc-TMPyP4 & $423-439$ & 432.2 & $52.3 \%$ \\
5. & C-myc-TMPyP3 & $417-429$ & 425.3 & $39.5 \%$ \\
6. & C-myc-TMPyP2 & No shift & 421.7 & $14.7 \%$ \\
\hline
\end{tabular}

both $27 \mathrm{Bcl} 2$ and C-myc G-quadruplex sequences). In case of TMPyP3, the soret band has shifted from $417 \mathrm{~nm}$ to $431 \mathrm{~nm}$ (13-14 nm shift) and isobestic point is observed at around $426 \mathrm{~nm}$. In the case of TMPyP2 the soret band does not show a shift from $414 \mathrm{~nm}$ and an isobestic point is observed at around $422 \mathrm{~nm}$. Percentage of hypochromicity for each Gquadruplex DNA is calculated by following the procedure described by Keating and Szalai [32]. The details of UV-Vis spectral studies are shown in Table 1. Results demonstrate that both quadruplex DNA's can interact with TMPyP3 and TMPyP4 drugs. But among them, TMPyP4 interaction with C-myc and $27 \mathrm{Bcl} 2$ quadruplex DNA is more efficient than TMPyP3. TMPyP2 has very little or no interaction. Similar observations have been made by Anantha et al. [35]. They showed that TMPyP4 exhibits both intercalation and external binding. From UV spectral analysis, it is evident that the isobestic point when TMPyP4 interacts with $27 \mathrm{Bcl} 2$ quadruplex DNA shows slight deviation at the end (isobestic point is not a tight single point). This indicates that interaction involves multiple steps. Where as with C-myc quadruplex DNA, the isobestic point does not show any deviation (a tight point is observed). Similar observations were made while observing the drug-DNA interaction, fluorimetrically.

3.3. Job Plot. Job plots make it possible to find out the stoichiometry interactions between drugs and quadruplex DNA. From Figure 3, it is evident that four molecules of TMPyP4 are interacting with each molecule of C-myc and 27Bcl2 quadruplex DNA. Similar observations have been made by Freyer et al. [26] only two molecules of TMPyP2 and TMPyP3 are interacting with each quadruplex DNA complex. The variation in the number of drug molecules interacting with quadruplex DNA is probably due to the placement and rotation of methyl groups placed on the porphyrin molecule. In the case of TMPyP4, the $\mathrm{N}-\mathrm{CH}_{3}$ group is in the para position and it has about $360^{\circ}$ degree of rotation along the axis. Hence the molecules can attain perfect planar structure when it is interacting with quadruplex DNA. Due to this reason, it can intercalate as well as bind externally to quadruplex DNA molecule. In the case 
TABLE 2: Data obtained from Job plot of Bcl2 and C-myc G-quadruplex DNA with TMPyP4, TMPyP3, and TMPyP2 porphyrin drugs.

\begin{tabular}{llll}
\hline S. No. & $\begin{array}{l}\text { Name of gquadrupelx DNA } \\
\text { and porphyrin }\end{array}$ & $\begin{array}{l}\text { Value of mole fraction of } \\
\text { porphyrin matching with } \\
\text { point of intersection }\end{array}$ & $\begin{array}{l}\text { Stoichiometry between } \\
\text { gquadruplex DNA } \\
\text { porphyrin }\end{array}$ \\
\hline 1. & 27Bcl2-TMPyP4 & 0.78 & $1: 3.54$ \\
2. & 27Bcl2-TMPyP3 & 0.70 & $1: 2.33$ \\
3. & 27Bcl2-TMPyP2 & 0.58 & $1: 1.38$ \\
4. & C-myc-TMPyP4 & 0.76 & $1: 3.17$ \\
5. & C-myc-TMPyP3 & 0.70 & $1: 2.33$ \\
6. & C-myc-TMPyP2 & 0.58 & $1: 1.38$ \\
\hline
\end{tabular}

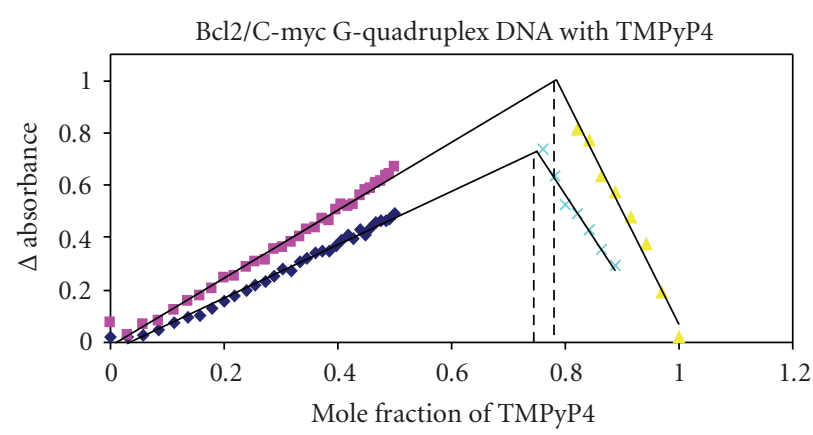

(a)

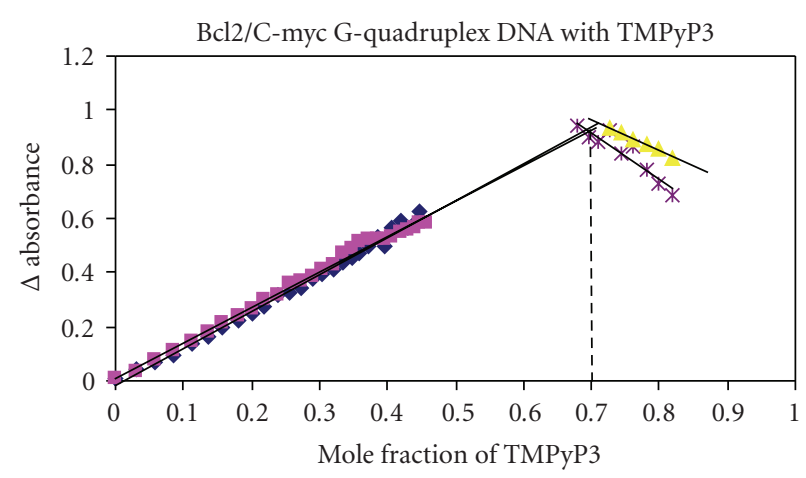

(b)

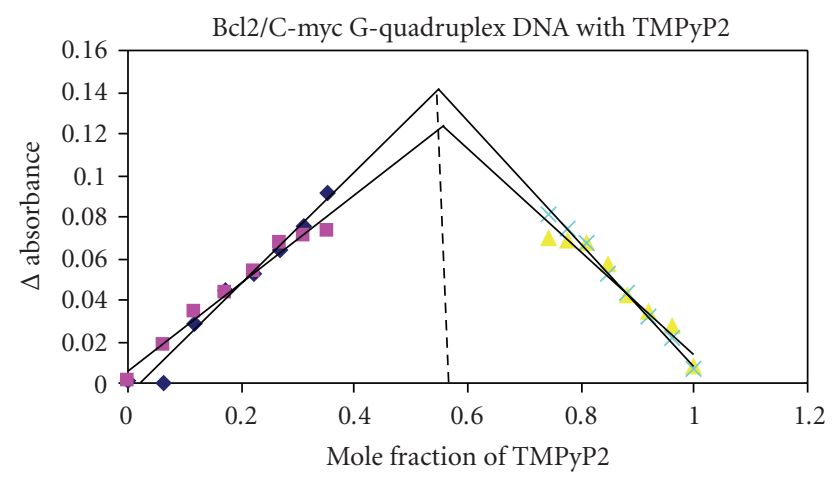

(c)

FIGURE 3: Job plots for the titration of the 27Bcl2 mid promoter and C-myc quadruplex DNA on interaction with TMPyP2, TMPyP3, and TMPyP4 drugs. Point of intersection of two lines is indicated by a dashed line. of TMPyP3 the $\mathrm{N}-\mathrm{CH}_{3}$ group is in meta position and it can have a restricted rotation on its axis. Therefore, this molecule cannot attain perfect coplanarity, like TMPyP4. Hence it cannot intercalate completely in between two G-quartets but prefers to bind externally. With TMPyP2, the $\mathrm{N}-\mathrm{CH}_{3}$ groups are in ortho position. The $\mathrm{N}-\mathrm{CH}_{3}$ groups have much more restricted rotation on its axis, in case of TMPyP2. Hence, the molecule is incapable of attaining perfect planar structure, exhibits intercalation with quadruplex DNA and shows only external binding. Probably due to this reason, TMPyP4 can intercalate and bind externally, and the drug: quadruplex DNA stoichiometry is $4: 1$. Where as, TMPyP2 and TMPyP3 prefers to bind externally and the stoichiometry is $2: 1$. Details were shown in Table 2.

3.4. Fluorescence Hypochromicity. In order to study the effect of buffer cationic strength on drug binding to quadruplex DNA, fluorescence titration was carried out in different KBPS buffers with variation in potassium ion concentrations (30 mM, $100 \mathrm{mM}, 200 \mathrm{mM}$, and $600 \mathrm{mM}$ ). Results emphasize that fluorescence hypochromicity decreases with increase of buffer salt concentration. It demonstrates that as the positive ion cloud around quadruplex complex increases, it occupies the available binding sites on quadruplex complex surface and reduces the possibility for drug molecules to bind exterior of quadruplex DNA. A decrease in fluorescence intensity of the drug may also be due to quenching by the surrounding water molecules. But if the drug molecule shows an intercalative mode of binding, quenching of fluorescence intensity is comparatively less. Because drug molecules are sandwiched between two G-quartets, the distance between guanine bases in quadruplex and the drug molecules becomes less. As the drug molecules come close to guanines in quadruplex, energy transfer between them takes place, which results in an increase of fluorescence. An increase in fluorescence intensity by energy transfer between DNA bases and the drug molecules, on intercalation, was reported earlier [36, 37]. The extent of fluorescence attenuation is not the same with all the three porphyrin drugs. It is more with TMPyP2, moderate with TMPyP3 and less with TMPyP4. These results indicate that TMPyP4 can show both intercalative as well as end binding to quadruplex complex while TMPyP3, and TMPyP2 prefer to bind externally. From Tables 3(a) and 3(b) it is evident that percentage of 
TABLE 3

(a) Effect of ionic strength on the percentage of fluorescence hypochromicity while $27 \mathrm{Bcl} 2$ interacts with porphyrin drugs.

\begin{tabular}{|c|c|c|c|}
\hline S. No. & $\begin{array}{l}\text { Ionic strength of } \\
\text { KBPES buffer } \\
(\mathrm{pH} 7.0)\end{array}$ & $\begin{array}{l}\text { Stoichiometry } \\
\text { DNA : drug }\end{array}$ & $\begin{array}{c}\text { Percentage of fluorescence } \\
\text { hypochromicity }\end{array}$ \\
\hline 1. & \multicolumn{3}{|c|}{ TMPyP4 with 27BCL2 } \\
\hline 1.a & $30 \mathrm{mM}$ & $1: 4$ & $34.2 \%$ \\
\hline 1.b & $100 \mathrm{mM}$ & $1: 4$ & $28.5 \%$ \\
\hline 1.c & $200 \mathrm{mM}$ & $1: 4$ & $20.3 \%$ \\
\hline 1.d & $600 \mathrm{mM}$ & $1: 4$ & $6.5 \%$ \\
\hline 2. & \multicolumn{3}{|c|}{ TMPyP3 with 27BCL2 } \\
\hline \multirow{2}{*}{ 2.a } & \multirow{2}{*}{$30 \mathrm{mM}$} & $1: 2$ & $59.8 \%$ \\
\hline & & $1: 3$ & $51.5 \%$ \\
\hline \multirow{2}{*}{ 2.b } & \multirow{2}{*}{$100 \mathrm{mM}$} & $1: 2$ & $52.5 \%$ \\
\hline & & $1: 3$ & $49.5 \%$ \\
\hline \multirow{2}{*}{ 2.c } & \multirow{2}{*}{$200 \mathrm{mM}$} & $1: 2$ & $33.6 \%$ \\
\hline & & $1: 3$ & $16.6 \%$ \\
\hline \multirow{2}{*}{ 2.d } & \multirow{2}{*}{$600 \mathrm{mM}$} & $1: 2$ & $8.6 \%$ \\
\hline & & $1: 3$ & $4.9 \%$ \\
\hline 3. & \multirow{3}{*}{$30 \mathrm{mM}$} & TMPyP2 with 27BCL2 & \\
\hline \multirow{2}{*}{ 3.a } & & $1: 2$ & $37.4 \%$ \\
\hline & & $1: 3$ & $40.2 \%$ \\
\hline \multirow{2}{*}{ 3.b } & \multirow{2}{*}{$100 \mathrm{mM}$} & $1: 2$ & $11.9 \%$ \\
\hline & & $1: 3$ & $12.3 \%$ \\
\hline \multirow{2}{*}{ 3.c } & \multirow{2}{*}{$200 \mathrm{mM}$} & $1: 2$ & $6.5 \%$ \\
\hline & & $1: 3$ & $4.4 \%$ \\
\hline \multirow{2}{*}{ 3.d } & \multirow{2}{*}{$600 \mathrm{mM}$} & $1: 2$ & $0.7 \%$ \\
\hline & & $1: 3$ & $0.3 \%$ \\
\hline
\end{tabular}

(b) Effect of ionic strength on the percentage of fluorescence hypochromicity while C-myc interacts with porphyrin drugs.

\begin{tabular}{|c|c|c|c|}
\hline S. No. & $\begin{array}{l}\text { Ionic strength of } \\
\text { KBPES buffer } \\
(\mathrm{pH} 7.0)\end{array}$ & $\begin{array}{l}\text { Stoichiometry } \\
\text { DNA : drug }\end{array}$ & $\begin{array}{c}\text { Percentage of fluorescence } \\
\text { hypochromicity }\end{array}$ \\
\hline 1. & & TMPyP4 with C-myc & \\
\hline 1.a & $30 \mathrm{mM}$ & $1: 4$ & $39.2 \%$ \\
\hline 1.b & $100 \mathrm{mM}$ & $1: 4$ & $32.6 \%$ \\
\hline 1.c & $200 \mathrm{mM}$ & $1: 4$ & $29.3 \%$ \\
\hline 1.d & $600 \mathrm{mM}$ & $1: 4$ & $5.5 \%$ \\
\hline 2. & \multirow{3}{*}{$30 \mathrm{mM}$} & TMPyP3 with C-myc & \\
\hline \multirow{2}{*}{ 2.a } & & $1: 2$ & $52.8 \%$ \\
\hline & & $1: 3$ & $49.5 \%$ \\
\hline \multirow{2}{*}{$2 . b$} & \multirow{2}{*}{$100 \mathrm{mM}$} & $1: 2$ & $47.5 \%$ \\
\hline & & $1: 3$ & $42.2 \%$ \\
\hline \multirow{2}{*}{ 2.c } & \multirow{2}{*}{$200 \mathrm{mM}$} & $1: 2$ & $29.6 \%$ \\
\hline & & $1: 3$ & $12.6 \%$ \\
\hline \multirow{2}{*}{ 2.d } & \multirow{2}{*}{$600 \mathrm{mM}$} & $1: 2$ & $6.6 \%$ \\
\hline & & $1: 3$ & $3.9 \%$ \\
\hline 3. & \multirow{3}{*}{$30 \mathrm{mM}$} & TMPyP2 with C-myc & \\
\hline \multirow{2}{*}{ 3.a } & & $1: 2$ & $42.4 \%$ \\
\hline & & $1: 3$ & $37.2 \%$ \\
\hline
\end{tabular}


(b) Continued.

\begin{tabular}{|c|c|c|c|}
\hline S. No. & $\begin{array}{l}\text { Ionic strength of } \\
\text { KBPES buffer } \\
(\mathrm{pH} 7.0)\end{array}$ & $\begin{array}{l}\text { Stoichiometry } \\
\text { DNA : drug }\end{array}$ & $\begin{array}{c}\text { Percentage of fluorescence } \\
\text { hypochromicity }\end{array}$ \\
\hline \multirow{2}{*}{ 3.b } & \multirow{2}{*}{$100 \mathrm{mM}$} & $1: 2$ & $12.6 \%$ \\
\hline & & $1: 3$ & $7.2 \%$ \\
\hline \multirow{2}{*}{ 3.c } & \multirow{2}{*}{$200 \mathrm{mM}$} & $1: 2$ & $7.8 \%$ \\
\hline & & $1: 3$ & $5.4 \%$ \\
\hline \multirow{2}{*}{ 3.d } & \multirow{2}{*}{$600 \mathrm{mM}$} & $1: 2$ & $0.6 \%$ \\
\hline & & $1: 3$ & $0.2 \%$ \\
\hline
\end{tabular}

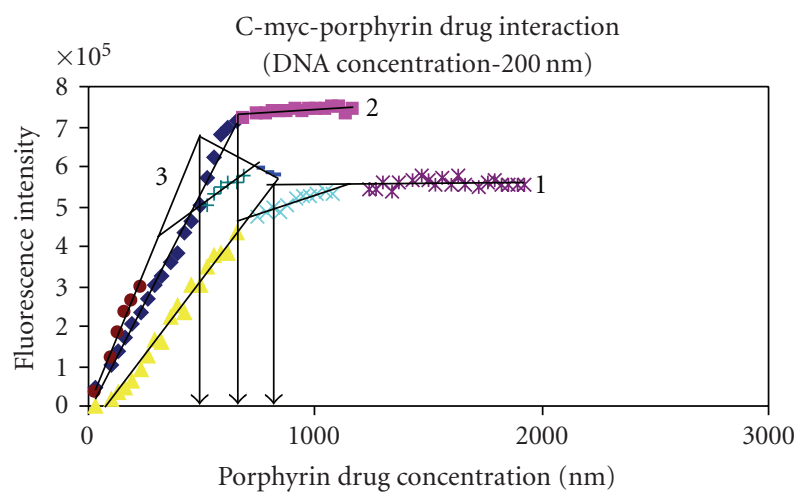

1: TMPyP4 3: TMPyP2

2: TMPyP3

(a)

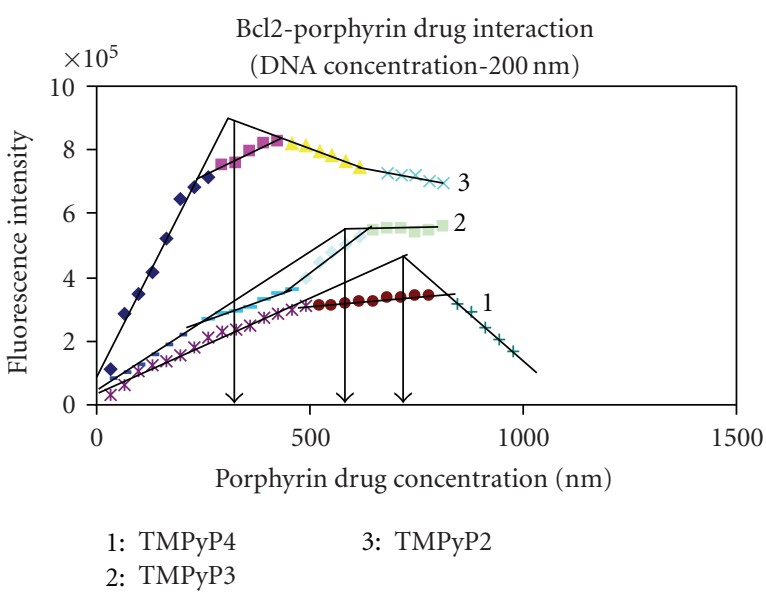

(b)

Figure 4: Fluorescence titration curves. $200 \mathrm{nM}$ quadruplex DNA is titrated with $0-1200 \mathrm{~nm}$ concentration of three different porphyrin drugs. Stoichiometry is considered at saturation levels. Hence the slop of initial and end points are considered.1: TMPyP4, 2: TMPyP3, and 3: TMPyP2.

fluorescence hypochromicity is comparatively higher (from lower to higher ionic strength), in the case of TMPyP3 and TMPyP2. This indicates that drug molecules are quenched by the surrounding water molecules. But, in thecase of TMPyP4, fluorescence attenuation is gradual. This demonstrates that though there is quenching of TMPyP4 fluorescence by surrounding water molecules, there is some increase in the fluorescence, due to energy transfer between TMPyP4 and guanines in the quadruplex on drug intercalation. Due to this, TMPyP4 could exhibit fluorescence even at $600 \mathrm{mM}$ salt concentration. Where as in case of TMPyP2 and TMPyP3 fluorescence intensity is almost quenched by the surrounding water molecules, as they are binding externally. The results obtained with $27 \mathrm{Bcl} 2$ as well as $\mathrm{C}$-myc quadruplex are shown in Tables 3(a) and 3(b), respectively.

3.5. Fluorescence Titration. In this study, $200 \mathrm{nM}$ of Gquadruplex DNA was considered for interaction with three different porphyrin drugs in the range of $0-1200 \mathrm{nM}$. From Figure 4 it is evident that the binding curve has multiple inflection points. $27 \mathrm{Bcl} 2$ shows a comparatively higher number of inflection points, indicating that the interaction occurs in multiple steps. Since it is intended to know the stoichiometry at saturation levels, only slopes of initial and final titrations are considered. The titration demonstrates that with one molecule of G-quadruplex DNA, four molecules of TMPyP4 and two molecules of TMPyP2 and TMPyP3 are interacting. It is also clear that the saturation point is occurring relatively at lower concentration in case of TMPyP2 (as the slope of binding curve is steep), moderate in TMPyP3, and at higher concentration in TMPyP4. The reason for difference in the nature of interaction of three porphyrins with quadruplex DNA is probably due to the orientation of $\mathrm{N}-\mathrm{CH}_{3}$ groups on the drug molecule and the nature of binding.

\section{Conclusions}

From the present study, it can be concluded that cationic porphyrins show different modes of binding to G-quadruplex DNA. The nature of binding depends upon the position of the bulky $\mathrm{N}^{+}-\mathrm{CH}_{3}$ groups on porphyrin. Experiments with $\mathrm{CD}$, fluorescence, and UV-Vis spectroscopic techniques indicate that TMPyP4 can bind externally as well as intercalate between the two G-tetrads. Two porphyrins, TMPyP3 and TMPyP2, prefer external binding to G-quadruplex DNA. Job plots and fluorescence binding curves indicate that four molecules of TMPyP4 and two molecules of TMPyP2 and TMPyP3 interact with 27Bcl2/C-myc G-quadruplex DNA. As the ionic strength of the buffer increases, fluorescence 
hypochromicity decreases. The extent of reduction in fluorescence hypochromicity is high in TMPyP2 and TMPyP3, and moderate in the case of TMPyP4. The variation in fluorescence hypochromicity is probably due to the difference in the mode of drug interaction with quadruplex DNA.

\section{Acknowledgments}

N. Nagesh and V. K. Sharma are thankful to Dr. Lalji Singh, Director of CCMB, Hyderabad, India for his encouragement and support given to undertake this work. N. Nagesh and V. K. Sharma contributed equally to this work.

\section{References}

[1] J. J. Cohen and R. C. Duke, "Glucocorticoid activation of a calcium-dependent endonuclease in thymocyte nuclei leads to cell death," Journal of Immunology, vol. 132, no. 1, pp. 38-42, 1984.

[2] T. J. McDonnell, P. Troncoso, S. M. Brisbay, et al., "Expression of the protooncogene bcl-2 in the prostate and its association with emergence of androgen-independent prostate cancer," Cancer Research, vol. 52, no. 24, pp. 6940-6944, 1992.

[3] G. B. Baretton, J. Diebold, G. Christoforis, et al., "Apoptosis and immunohistochemical bcl-2 expression in colorectal adenomas and carcinomas: aspects of carcinogenesis and prognostic significance," Cancer, vol. 77, no. 2, pp. 255-264, 1996.

[4] C. V. Dang, "c-Myc target genes involved in cell growth, apoptosis, and metabolism," Molecular and Cellular Biology, vol. 19, no. 1, pp. 1-11, 1999.

[5] C. V. Dang, L. M. S. Resar, E. Emison, et al., "Function of the c-Myc oncogenic transcription factor," Experimental Cell Research, vol. 253, no. 1, pp. 63-77, 1999.

[6] M. D. Cole, "The Myc oncogene: its role in transformation and differentiation," Annual Review of Genetics, vol. 20, pp. 361$384,1986$.

[7] M. Henriksson, G. Selivanova, M. Lindström, and K. G. Wiman, "Inactivation of Myc-induced p53-dependent apoptosis in human tumors," Apoptosis, vol. 6, no. 1-2, pp. 133-137, 2001.

[8] L. M. Boxer and C. V. Dang, "Translocations involving c-Myc and c-Myc function," Oncogene, vol. 20, pp. 5595-5610, 2001.

[9] M. Bejugam, S. Sewitz, P. S. Shirude, R. Rodriguez, R. Shahid, and S. Balasubramanian, "Trisubstituted isoalloxazines as a new class of G-quadruplex binding ligands: small molecule regulation of c-kit oncogene expression," Journal of the American Chemical Society, vol. 129, no. 43, pp. 12926-12927, 2007.

[10] D. Sun, B. Thompson, B. E. Cathers, et al., "Inhibition of human telomerase by a G-quadruplex-interactive compound," Journal of Medicinal Chemistry, vol. 40, no. 14, pp. 2113-2116, 1997.

[11] A. M. Burger, F. Dai, C. M. Schultes, et al., "The Gquadruplex-interactive molecule BRACO-19 inhibits tumor growth, consistent with telomere targeting and interference with telomerase function," Cancer Research, vol. 65, no. 4, pp. 1489-1496, 2005.

[12] O. Y. Fedoroff, M. Salazar, H. Han, V. V. Chemeris, S. M. Kerwin, and L. H. Hurley, "NMR-based model of a telomerase-inhibiting compound bound to G-quadruplex DNA," Biochemistry, vol. 37, no. 36, pp. 12367-12374, 1998.
[13] J. F. Riou, L. Guittat, P. Mailliet, et al., "Cell senescence and telomere shortening induced by a new series of specific G-quadruplex DNA ligands," Proceedings of the National Academy of Sciences of the United States of America, vol. 99, no. 5, pp. 2672-2677, 2002.

[14] T. M. Fletcher, "Telomerase: a potential therapeutic target for cancer," Expert Opinion on Therapeutic Targets, vol. 9, no. 3, pp. 457-469, 2005.

[15] J. Seenisamy, S. Bashyam, V. Gokhale, et al., "Design and synthesis of an expanded porphyrin that has selectivity for the c-Myc G-quadruplex structure," Journal of the American Chemical Society, vol. 127, no. 9, pp. 2944-2959, 2005.

[16] F. X. Han, R. T. Wheelhouse, and L. H. Hurley, "Interactions of TMPyP4 and TMPyP2 with quadruplex DNA. Structural basis for the differential effects on telomerase inhibition," Journal of the American Chemical Society, vol. 121, no. 15, pp. 3561-3570, 1999.

[17] T. Kimura, K. Kawai, M. Fujitsuka, and T. Majima, "Detection of the G-quadruplex-TMPyP4 complex by 2-aminopurine modified human telomeric DNA," Chemical Communications, no. 4, pp. 401-402, 2006.

[18] H. Han, D. R. Langley, A. Rangan, and L. H. Hurley, "Selective interactions of cationic porphyrins with G-quadruplex structures," Journal of the American Chemical Society, vol. 123, no. 37, pp. 8902-8913, 2001.

[19] A. B. Guliaev and N. B. Leontis, "Cationic 5,10,15,20-tetrakis (N-methylpyridinium-4-yl) porphyrin fully intercalates at $5^{\prime}$ CG-3' steps of duplex DNA in solution," Biochemistry, vol. 38, no. 47, pp. 15425-15437, 1999.

[20] L. G. Marzilli, D. L. Banville, G. Zon, and W. D. Wilson, "Pronounced $1 \mathrm{H}$ and $31 \mathrm{P}$ NMR spectral changes on meso-tetrakis(N-methylpyridinium-4-yl)porphyrin binding to tetradecaoligo-deoxyribonucleotides: evidence for symmetric, selective binding to $5^{\prime} \mathrm{CG} 3^{\prime}$ sequences," Journal of the American Chemical Society, vol. 108, no. 14, pp. 4188-4192, 1986.

[21] T. Ohyama, H. Mita, and Y. Yamamoto, "Binding of 5,10,15,20-tetrakis(N-methylpyridinium-4-yl)-21H,23Hporphyrin to an at-rich region of a duplex DNA," Biophysical Chemistry, vol. 113, no. 1, pp. 53-59, 2005.

[22] J. O. Kim, Y. A. Lee, B. H. Yun, S. W. Han, S. T. Kwag, and S. K. Kim, "Binding of meso-tetrakis(N-methylpyridinium-4yl)porphyrin to AT oligomers: effect of chain length and the location of the porphyrin stacking," Biophysical Journal, vol. 86, no. 2, pp. 1012-1017, 2004.

[23] K. G. Ford and S. Neidle, "Perturbations in DNA structure upon interaction with porphyrins revealed by chemical probes, DNA footprinting and molecular modelling," Bioorganic and Medicinal Chemistry, vol. 3, no. 6, pp. 671-677, 1995.

[24] S. Lee, S. H. Jeon, B. J. Kim, S. W. Han, H. G. Jang, and S. K. Kim, "Classification of CD and absorption spectra in the Soret band of $\mathrm{H}_{2} \mathrm{TMPyP}$ bound to various synthetic polynucleotides," Biophysical Chemistry, vol. 92, no. 1-2, pp. 35-45, 2001.

[25] I. Haq, J. O. Trent, B. Z. Chowdhry, and T. C. Jenkins, "Intercalative G-tetraplex stabilization of telomeric DNA by a cationic porphyrin," Journal of the American Chemical Society, vol. 121, no. 9, pp. 1768-1779, 1999.

[26] M. W. Freyer, R. Buscaglia, K. Kaplan, D. Cashman, L. H. Hurley, and E. A. Lewis, "Biophysical studies of the c-Myc NHE III $_{1}$ promoter: model quadruplex interactions with a cationic porphyrin," Biophysical Journal, vol. 92, no. 6, pp. 2007-2015, 2007. 
[27] G. D. Fassman, "Nucleic acids," in Handbook of Biochemistry and Molecular Biology, CRC, Cleveland, Ohio, USA, 1975.

[28] G. E. Plum, "Determination of oligonucleotide molar extinction coefficients," in Current Protocols in Nucleic Acid Chemistry, vol. 7.3, pp. 1-17, John Wiley \& Sons, New York, NY, USA, 2000.

[29] R. F. Pasternack, P. R. Huber, P. Boyd, et al., "Aggregation of meso-substituted water-soluble porphyrins," Journal of the American Chemical Society, vol. 94, no. 13, pp. 4511-4517, 1972.

[30] K. Kalyanasundaram, "Photochemistry of water-soluble porphyrins: comparative study of isomeric tetrapyridyl- and tetrakis(N-methylpyridiniumyl)porphyrins," Inorganic Chemistry, vol. 23, no. 16, pp. 2453-2459, 1984.

[31] P. Hambright, T. Gore, and M. Burton, "Synthesis and characterization of new isomeric water-soluble porphyrins. Tetra(2-N-methylpyridyl)porphine and tetra(3N-methylpyridyl)porphine," Inorganic Chemistry, vol. 15, no. 9, pp. 2314-2315, 1976.

[32] L. R. Keating and V. A. Szalai, "Parallel-stranded guanine quadruplex interactions with a copper cationic porphyrin," Biochemistry, vol. 43, no. 50, pp. 15891-15900, 2004.

[33] W. Likussar and D. F. Boltz, "Theory of continuous variations plots and a new method for spectrophotometric determination of extraction and formation constants," Analytical Chemistry, vol. 43, no. 10, pp. 1265-1272, 1971.

[34] K. C. Ingham, "On the application of Job's method of continuous variation to the stoichiometry of protein-ligand complexes," Analytical Biochemistry, vol. 68, no. 2, pp. 660663, 1975.

[35] N. V. Anantha, M. Azam, and R. D. Sheardy, "Porphyrin binding to quadruplexed $\mathrm{T}_{4} \mathrm{G}_{4}$," Biochemistry, vol. 37, no. 9, pp. 2709-2714, 1998.

[36] I. Lubitz, N. Borovok, and A. Kotlyar, "Interaction of monomolecular G4-DNA nanowires with TMPyP: evidence for intercalation," Biochemistry, vol. 46, no. 45, pp. 1292512929, 2007.

[37] D. Suh and J. B. Chaires, "Criteria for the mode of binding of DNA binding agents," Bioorganic and Medicinal Chemistry, vol. 3, no. 6, pp. 723-728, 1995. 

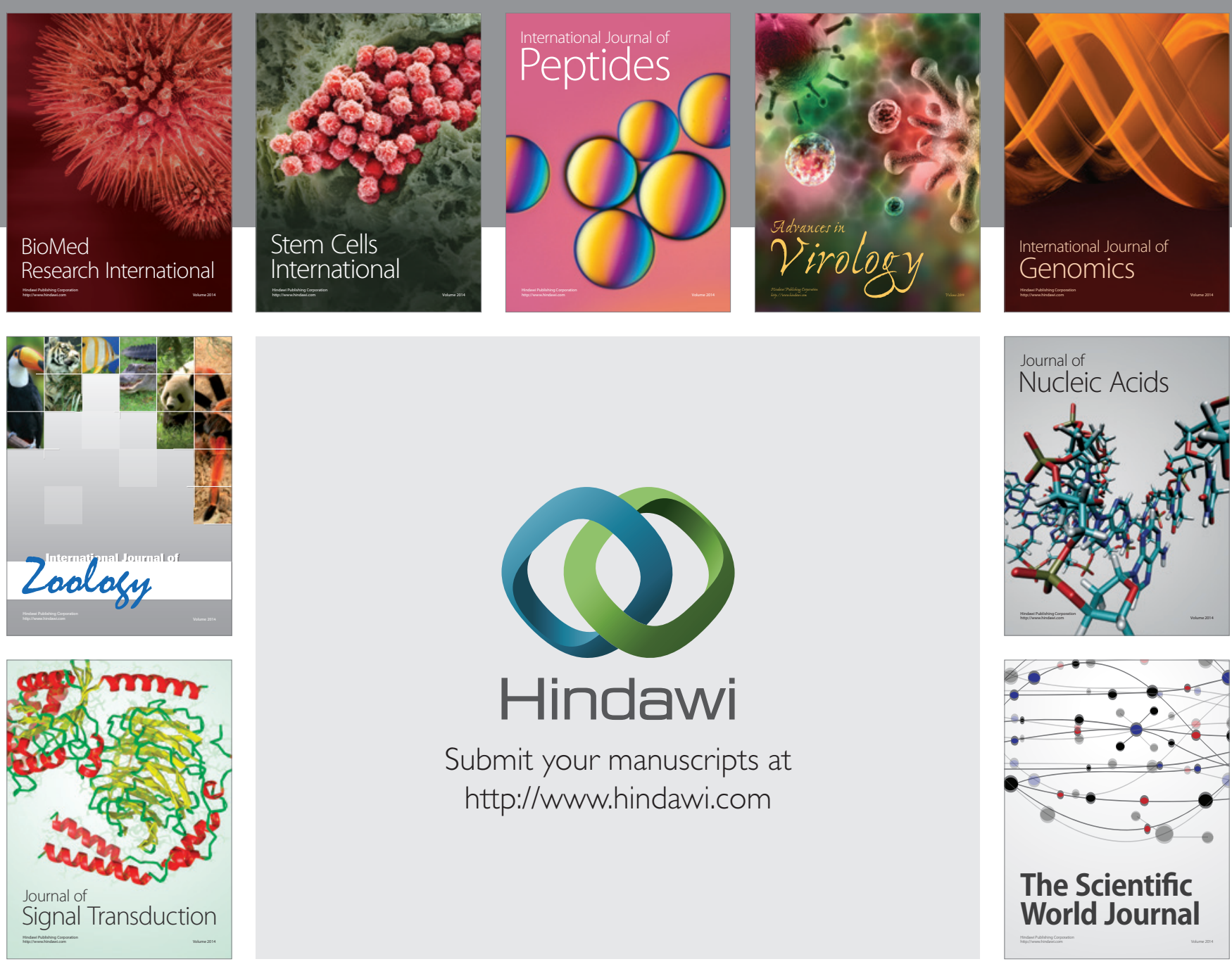

Submit your manuscripts at

http://www.hindawi.com
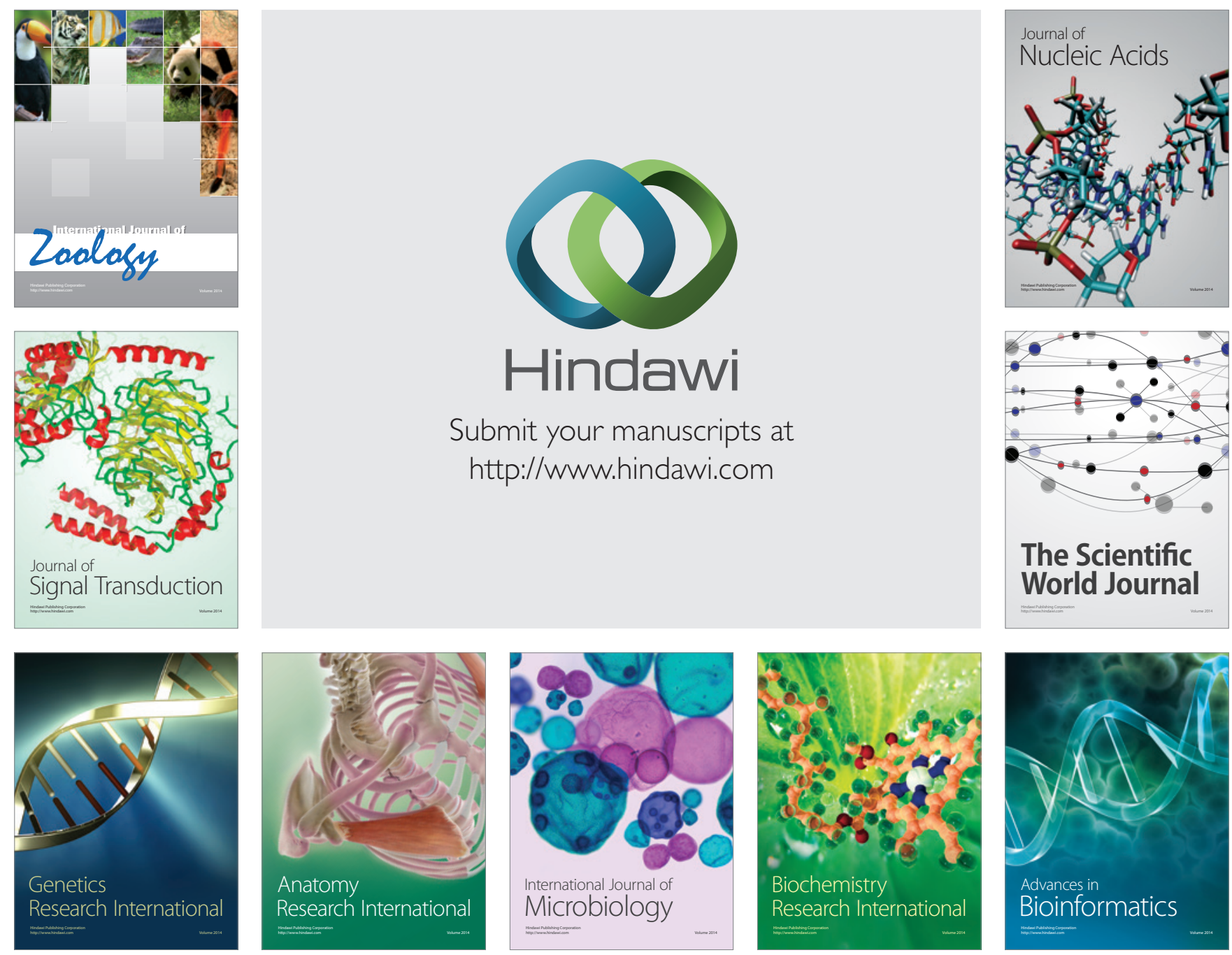

The Scientific World Journal
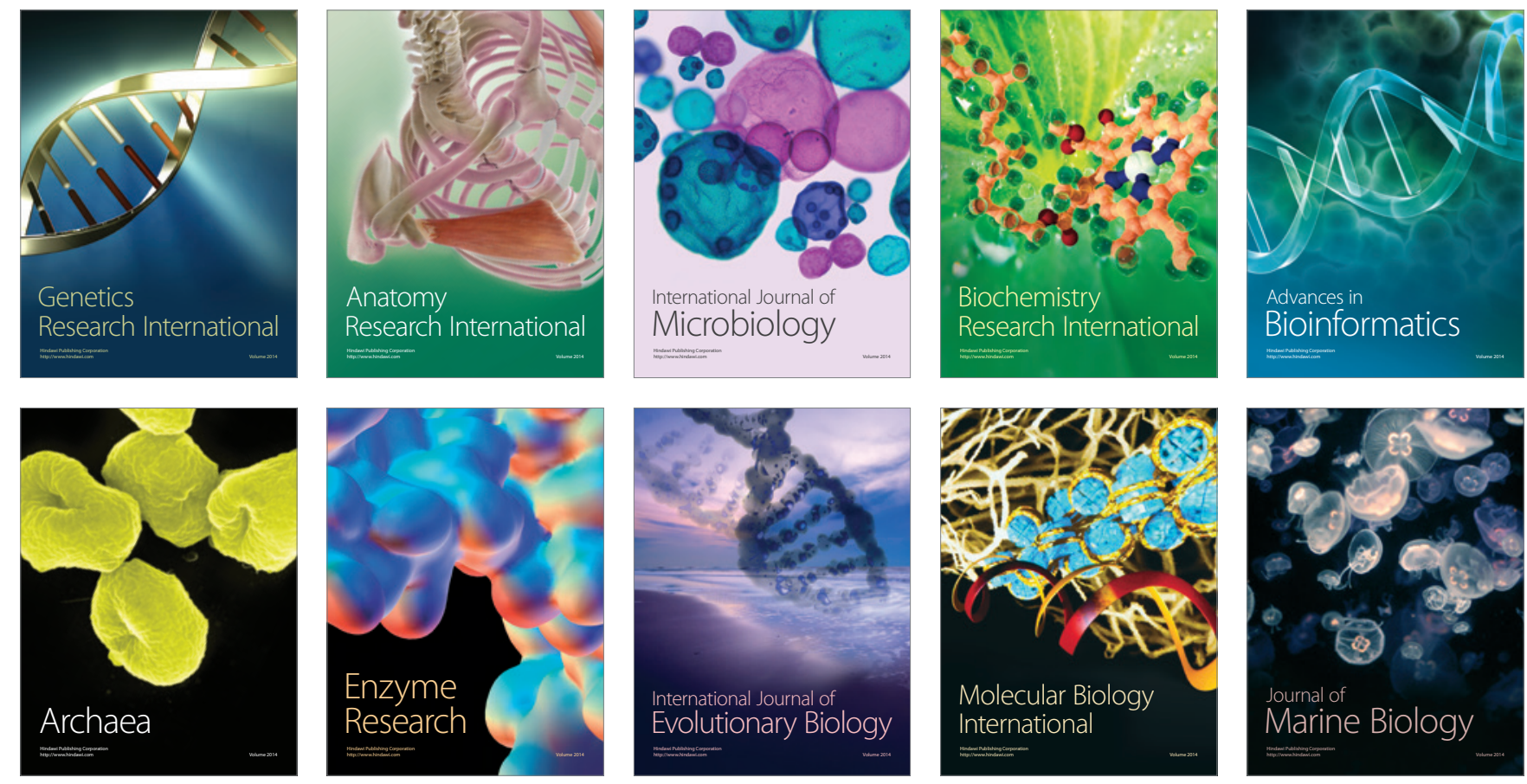